IZA DP No. 4553

Delaying the Bell: The Effects of Longer School Days on Adolescent Motherhood in Chile

Diana I. Kruger

Matias E. Berthelon

November 2009 


\title{
Delaying the Bell: \\ The Effects of Longer School Days on Adolescent Motherhood in Chile
}

\author{
Diana I. Kruger \\ Catholic University of Valparaiso \\ and IZA \\ Matias E. Berthelon \\ Catholic University of Valparaiso
}

Discussion Paper No. 4553

November 2009

\author{
IZA \\ P.O. Box 7240 \\ 53072 Bonn \\ Germany \\ Phone: +49-228-3894-0 \\ Fax: +49-228-3894-180 \\ E-mail: iza@iza.org
}

Any opinions expressed here are those of the author(s) and not those of IZA. Research published in this series may include views on policy, but the institute itself takes no institutional policy positions.

The Institute for the Study of Labor (IZA) in Bonn is a local and virtual international research center and a place of communication between science, politics and business. IZA is an independent nonprofit organization supported by Deutsche Post Foundation. The center is associated with the University of Bonn and offers a stimulating research environment through its international network, workshops and conferences, data service, project support, research visits and doctoral program. IZA engages in (i) original and internationally competitive research in all fields of labor economics, (ii) development of policy concepts, and (iii) dissemination of research results and concepts to the interested public.

IZA Discussion Papers often represent preliminary work and are circulated to encourage discussion. Citation of such a paper should account for its provisional character. A revised version may be available directly from the author. 
IZA Discussion Paper No. 4553

November 2009

\section{ABSTRACT \\ Delaying the Bell: The Effects of Longer School Days on Adolescent Motherhood in Chile ${ }^{*}$}

We analyze the effect of a Chilean school reform that lengthened the school day from half to full-day shifts on the likelihood that adolescent girls become mothers. By increasing the number of hours spent in school, the reform curtails opportunities to engage in risky sexual behaviors. Using Chile's socio-economic household surveys and administrative data from the Ministry of Education from 1990-2006, we exploit the exogenous time and regional variation in the implementation of the reform to identify the effects of increased education and adult supervision on the likelihood that adolescent girls become mothers. We find that access to full-day schools reduces the probability of becoming an adolescent mother among poor families and in urban areas: an increase in full-day municipal enrollment of $20 \%$ reduces the likelihood of teen motherhood by $5 \%$.

JEL Classification: H51, I18, I28, J13, O15

Keywords: adolescent motherhood, adolescent pregnancy, school day reform, Chile

Corresponding author:

Diana I. Kruger

Catholic University of Valparaiso

School of Business Administration

Avenida Brasil 2830, Piso 7

Valparaiso

Chile

E-mail: diana.kruger@ucv.cl

\footnotetext{
* We would like to thank Sergio Avalos for excellent research assistance and Juan Pablo Valenzuela for helpful discussions and suggestions. The paper also benefited from comments of seminar participants at Northwestern University, Dartmouth College, The University of Chile, the Catholic University of Chile and the 2009 Meeting of the Chilean Economics Association (SECHI). All errors and omissions are our own. The authors received financial support from Chile's National Committee of Scientific and Technological Research (Comisión Nacional de Investigación Científica y Tecnológica, CONICYT), through FONDECYT Project No.1070447.
} 


\section{Introduction}

One of every four girls is a mother in Chile by the time she is 19 years old. Adolescent pregnancy and motherhood are of great concern to policy makers to the extent that they reduce women's educational attainments and worsen their future labor market opportunities and outcomes. Since the proportion of teens that are mothers is higher among the poor — one of every three low-income 19-year olds in Chile—-then one should also be concerned about intergenerational transmissions of poverty brought on at least in part by early childbearing.

The literature analyzing the relationship between teenage motherhood and women’s future outcomes is vast, and although much of the empirical debate questions the causal impact of early motherhood on various future outcomes, ${ }^{1}$ most recent work finds a causal and negative effect of adolescent motherhood on outcomes such as education attainment, income, and employment (Fletcher and Wolfe, 2008; Ashcraft and Lang, 2006). Thus, policies that delay childbearing beyond adolescence should have a positive impact on women's future labor market opportunities and economic well being. Since poorer women are more likely to be teen moms, these policies may also help break an inherited cycle of poverty.

Although early childbearing may affect adolescents' educational attainments, it is also likely that more schooling may deter teen motherhood. The channels through which education may affect early fertility decisions are through a increasing a woman's permanent lifetime income and earnings, which induce lower fertility (Becker and Lewis 1963); through improved information about fertility options and reproductive health in general (Grossman 1972); and finally through expectations about the future (Wolfe et al. 2007; Wolfe et al. 2001).

Despite the potential role of education in delaying births into adulthood, it is still an area of research that is relatively unexplored, particularly in developing countries. The empirical challenge of estimating the effect of education on fertility in general, and teen births specifically, lies in the fact that unobserved characteristics such as ability or preferences may simultaneously determine an adolescent's schooling and fertility choices. Recent work uses identification strategies that rely on exogenous variation induced by

\footnotetext{
${ }^{1}$ Hoffman (1998) provides a clear summary of the causality debate.
} 
changes in mandatory schooling laws that affect educational attainment, and then estimate whether these changes affect teen motherhood. For instance, Black et al. (2008) analyze the impact of changes in compulsory schooling laws in the U.S. and in Norway on the likelihood that women gave birth as teenagers. For the U.S. estimations the authors use decennial census data from 1940 - 1980 and match it to mandatory schooling laws at the state where women were born. In the case of Norway they use the 1960 population census and match women's observed fertility outcomes to compulsory schooling laws in the municipality where she grew up. Their results reveal that in both the United States and Norway, mandating women to remain in school significantly reduces the likelihood of having a child in their adolescence.

McCrary and Royer (2006) study the relationship between women’s education and fertility decisions by looking at the effect of changes in age-at-school-entry policies in California and Texas. They compare the probability of motherhood of women who were born just before and just after the date by which they must have reached legal age of first entry into schools. The date of birth is used as a variable that exogenously affects educational attainment: women who were born immediately before the legal date of entry would have one additional year of education than women with similar characteristics and who were born after the date of entry. The authors find no effect of education on motherhood, and small effects of education on child health. However, their data comes from administrative birth records so that although well suited to analyze child health, is not ideal to analyze teenage motherhood since they only observe precisely women who gave births. $^{2}$

In this paper we analyze another potential channel between school and motherhood, more specifically, the relationship between number of hours spent in school and the likelihood of teenage motherhood. We study whether a school reform program in Chile, which extended the length of the school day, affected the likelihood that adolescent girls aged 15 to 19 years became mothers. The full-day school reform increased the amount of time that students spent in school from 32 to 39 hours per week.

\footnotetext{
${ }^{2}$ The authors constructed the control group—adolescents that did not give birth—from the states' population census.
} 
Operationally this change meant going to a system where Chilean schools provide only one full-day shift, ${ }^{3}$ increasing the amount of hours under adult supervision, as they are now required to remain on school grounds until 4:00 pm (compared to 1:00 pm under the previous system). Our study, therefore, is on the short-run impact of the change in the Chilean school day on adolescent motherhood, rather than the medium or long term effects of the greater amounts of education received by adolescents due to the increased number of hours spent in school. Since we analyze its short-run impact, any effect of the reform is likely coming from the fact that students spend a greater number of hours per day under adult supervision, limiting the possibility to engage in risky sexual behavior that can result in pregnancy. Policy makers in the United States have advocated lengthening the school day in order to alter certain behaviors among teens, such as juvenile delinquency, under the notion that busy kids stay out of trouble. Empirical evidence supports the idea that schools play a non-academic role in adolescent's lives: Jacob and Lefgren (2003) find that the incapacitation effects of schools are significant in reducing the incidence of certain types of juvenile crime-teenagers were $14 \%$ less likely to be involved in property crime on days when schools were in session relative to certain types of school holidays. In this paper, we propose that keeping Chilean adolescents on school grounds until the mid-afternoon reduced the incidence of pregnancy and motherhood. ${ }^{4}$

Our identification strategy relies on the gradual implementation of the full-day school reform, which provides both regional and time variation that is uncorrelated with adolescent motherhood ${ }^{5}$ Our data on adolescent motherhood comes from eight rounds of Chilean household surveys, while variables measuring access to full-day schools comes from administrative data on high school enrollment. Our regressions control for region-year trends, as well as municipal-level fixed effects to control for time-invariant differences across municipalities.

Our findings suggest that adolescent girls are less likely to become mothers if they live in a municipality that has a larger coverage of full-time high schools. The impact is present among poor teens and

\footnotetext{
${ }^{3}$ Before the reform, many schools_elementary and secondary_provided two or even three half-day shifts, morning, afternoon and evening.

${ }^{4}$ All forms of abortion, including therapeutic ones, are illegal in Chile, which is why this paper focuses on motherhood (there is no data or consistent estimates on illegal abortions).

${ }^{5}$ The reform began its implementation in 1997 and requires all schools receiving public funds to offer full-time shifts by 2010.
} 
has a modest effect: an increase of 20 percent in the municipal share of full-day high schools reduces the probability of motherhood in adolescence by almost 5 percent. We also find that the full-day school effects are only present in urban areas. Our results are robust to different sample specifications and estimation methods (OLS, Probit and Logit). ${ }^{6}$

These results have important messages and policy implications for Chilean authorities. Firstly, while the full-day reform has faced criticism for its meager impact on standardized test results ${ }^{7}$ — which was the main objective of the program—we find evidence of an indirect effect on adolescent behavior. The reduction in teen motherhood should improve young women’s future economic opportunities

Secondly, the strongest impacts of the reform occur among poor, urban youth—a vulnerable population that is the target of other government poverty alleviation programs. The full-day reform, through its impact on teen motherhood, has thus resulted in improved economic outlooks for underprivileged teenagers, which may contribute to reducing inequities in labor market opportunities faced by high vs. lowincome young women.

Finally, this paper contributes to the literature on the non-academic role of schools in the lives of underprivileged youths. Schools play a large role in society that goes beyond cognitive and academic skills learned in the classroom. In Chile, extending the school day and providing an environment with supervision has contributed to other policies aimed at delaying child birth beyond adolescence.

\section{Education sector reform: Full-Day Schooling}

Chile has implemented two major reforms in the education system over the last 25 years. The first wave of reforms, which has received attention from policy and academic circles, was carried out 1981. Two of the central elements of this reform were the creation of publicly funded, privately owned schools while simultaneously allowing families to select the public school of their choice. In post-reform Chile, schools are one of three categories: (i) public, which are administered by municipalities and funded entirely by the

\footnotetext{
${ }^{6}$ This paper only reports OLS results; estimates of Probit and Logit regressions yield almost identical results.

${ }^{7}$ Valenzuela (2005), Garcia (2006).
} 
central government; (ii) private subsidized (or “voucher”) schools, which are privately owned/managed but financed by a fixed per-student subsidy provided by the central government (which is the same as the student subsidy received by public schools); ${ }^{8}$ and (iii) private schools, which are privately owned, managed and financed and do not receive any government funding. The creation of voucher schools led to a dynamic education sector that underwent fast growth in the supply of schools (see Figure 1), with subsequent increases in enrollment rates in both primary and secondary levels. ${ }^{9}$ A large empirical literature exists measuring the impact that the school-finance reform had on outcomes such as attendance, earnings, access to higher education, and social mobility, among others. ${ }^{10}$

The second major reform—implemented gradually since 1997—sought to improve education quality in Chilean schools by increasing the amount of time that students spend in the classroom. ${ }^{11}$ The reform augmented instruction time by 30 percent without lengthening the academic calendar year, which amounted to an additional 1.4 hours of daily classroom time on average. The program presented operational challenges that essentially restructured how public schools function in Chile at both primary and secondary levels: schools changed from providing two half-day shifts to one full-day shift, which gave the reform its name, Full Day Schooling (henceforth FDS). ${ }^{12}$ The FDS program began implementation in 1997, and mandated that all schools that receive public funds—municipal or private subsidized—must offer a full-day program by 2007 and 2010, respectively. ${ }^{13}$ Additionally, the FDS law mandates that all publicly funded schools created after 1997 must begin their operations as full-time schools.

Implementation was gradual due to infrastructure and financial constraints (see more on costs below). The first schools to switch to the FDS regime were rural and smaller schools, which did not offer more than one half-day shifts; these were the first to change because the reform did not entail investing in

\footnotetext{
${ }^{8}$ Voucher schools are allowed to charge fees to its students.

${ }^{9}$ Increases in enrollment rates can also be attributed to a diverse set of policies such as: strict enforcement of mandatory primary school laws, transfers (scholarships) targeted to families whose children were more prone to drop out of school (due to poverty or location), provision of school supplies, meals, and more recently, to a new mandatory secondary school law approved in 2000.

${ }^{10}$ For instance: Hsieh and Urquiola (2006), Chay, McEwan and Urquiola (2005), Gallego (2002), Mizala and Romaguera (2000).

${ }^{11}$ This section draws from the program description in Valenzuela (2005).

12 The program was approved by law No.19,532. In Chile the program is referred to as JEC, which is the Spanish acronym for fullday schooling (“jornada escolar completa”).

${ }_{13}$ Private schools were not obliged to ascribe to the FDS program.
} 
infrastructure. During the first year of the FDS program, few secondary schools were able to change to fullday shifts, yet the number has increased gradually (see Figure 2).

Schools that wish to receive public funding for changing operations to FDS, can obtain funds through a competitive application process with the Ministry of Education, where they submit their academic plans and request the required funds to operate under the full day regime. Implementation of the FDS program has two types of expenses: operational and infrastructure costs. The operational component includes variable expenses that increase as a result of lengthening the amount of time children spend in school. For example, as a result of full-day shift, one major expenditure item (and operational challenge) is the provision of school lunches. To cover all operational costs, upon approving a school’s FDS program, the Government increases the size of their per-student subsidy (regularly paid to all public and voucher schools) by $40 \%$.

The most important expense (and limitation) associated with full-day school shifts was the expansion of schools' infrastructure to accommodate, in many cases, twice the number of students at any given time. In the application process, schools competed for limited capital infrastructure funds to finance their infrastructure requirements. The Ministry of Education did not allocate FDS funds randomly; rather, they selected schools by balancing two possibly opposing criteria: (i) schools with relatively low switch costs (i.e., rural schools, as described earlier) and (ii) priority schools with pre-existing deficits in infrastructure and located in areas of socio-economic vulnerability. The non-random nature of the adscription process can potentially affect the identification strategy and is discussed in section 3.1 below.

\subsection{The FDS reform and adolescent motherhood}

Although the FDS reform was implemented in order to improve school achievement, the changes in time allocation can potentially affect other household decisions. Under full-day schooling, students remain on school grounds until 4 p.m., whereas in the previous system most students would leave school grounds at approximately 1:00 p.m. The reform exogenously alters not only the number of hours students spend in the classroom, but also the way in which families organize their day. For instance, full-day schooling increases the number of hours that primary school-aged children spend under school supervision, reducing the need for 
childcare — which may facilitate female entry into the labor force. Indeed, Cabrera (2008) finds that the FDS reform increased female labor force participation of women with children of primary school age (the effect was statistically significant but economically small.)

Extending the time that adolescents spend in school increases their human capital accumulation, and at the same time reduces the number of hours that they spend without adult supervision. Thus, the FDS reform has the potential to affect adolescents' preferences for early parenthood—-through the human capital effect - and curtails the opportunity for risky sexual behavior. In this paper, we explore whether this extension of the school day had an impact on the likelihood that adolescent girls become mothers.

Adolescent motherhood is a serious problem in Chile. In Table 1, we present the age-specific ratios of adolescents who gave birth during the 1990-2004 period. The last column of the table presents the cumulative unconditional probability that an adolescent has given birth before her $20^{\text {th }}$ birthday. Although remarkable improvements have been observed since 1990, the most current year of data available reveals that approximately one of every four young women is a mother by the time she is 19 years old.

A closer look Table 1 reveals that the (unconditional) probability of motherhood in adolescence remained high and stable throughout the 1990s, and it experiences a precipitous drop since the year 2000. The age-specific trends reveal that teenage births remained stable until 1997, and for the younger age groups (15-17 year olds) the rate began to decrease as early as 1998—one year after the FDS reform was implemented (Figure 3).

This descriptive analysis suggests that the full-time school day may indeed be a determining factor that affects adolescent's preference and scope for risky sexual behavior, although establishing causality is a complex task. The FDS reform was complementary to other programs that sought to prevent high school desertion among poor households, and which may also have affected adolescents’ fertility decisions, such as: high-school scholarships (discretionary use by recipient), direct provision of school meals and school supplies.

Furthermore, in 2000 the Legislature approved two laws that may affect teenage education and motherhood: a law of mandatory secondary schooling, raising the minimum required education from 8 to 12 
years. ${ }^{14}$ That same year, the legislature approved an anti-discrimination law that prohibits publicly funded schools (i.e., municipal and voucher schools) from discriminating against female students due to pregnancy or maternity. ${ }^{15}$ Since the Chilean legal system is centralized, Laws apply to all citizens at the same time, which prevents us from empirically identifying a causal effect of either of these two laws on adolescent motherhood. However in our regressions we control for year-effects, which capture the effect of the 2000 legal reform, along with all events that occurred in that year.

\subsection{Adscription to Full-Day Schooling}

Schools did not change to the full-day regime randomly, or more specifically, the Ministry of Education did not allocate FDS funds randomly. Instead, the first to ascribe to the reform were those schools that faced low or no infrastructure costs due to the nature of their operation prior to 1997. Rural schools, as well as schools with low enrollment that functioned under only one shift prior to the reform, were the first to change.

An additional criterion in the allocation of funds was to prioritize schools with socio-economically vulnerable populations. If two identical schools in terms of infrastructure requirements, academic plans, and enrollment competed for funds in a given year, the funds would be allocated to the school with greater vulnerability.

Table 2 presents the pace of implementation of the FDS program from the initial year of the reform until 2006, as well as the relative size of the student population, in each of Chile's 13 administrative Regions. We observe an inverse relationship between relative size of enrollment and the level of implementation reached by 2006. The Santiago Metropolitan Region (RM) is home to approximately one third of Chile’s population and 37 percent of high school enrollment (Table 2). Yet in this Region, the FDS reform was slowest. The fastest change occurred in Regions XI and XII, where 95 and 91 percent of high schools had

\footnotetext{
14 The mandatory schooling law became part of the Constitution in 2003 (Law 19,876).

15 The Law instituting the rights of pregnant and adolescent mothers is Law No. 19,688. Prior to Law No. 19,688 public schools had the discretion to expel pregnant teens or discriminate them among peers by preventing participation in school activities, such as graduation ceremonies, which may have discouraged pregnant teens from completing high school. After the passage of law No. 19,688 schools are require to accommodate pregnant or lactating students.
} 
changed to a full day system by 2006 — yet less than 2 percent of secondary school enrollment is located in these two regions.

In order to estimate the effect of increased schooling on adolescent motherhood, we exploit the quasi-experimental nature of the FDS reform's implementation, which had, as Table 2 reveals, both time and regional variation.

\section{Empirical methodology}

We analyze whether the likelihood that an adolescent girl in Chile is a mother (Y) is affected by the availability of full-day high schools (FDS) in the municipality where she resides:

$$
\operatorname{Prob}\left(\mathrm{Y}_{\mathrm{ijt}}=1\right)=\alpha+\beta \mathrm{FDS}_{\mathrm{jt}}+\delta \mathrm{X}_{\mathrm{ijt}}+\mu \mathrm{M}_{\mathrm{jt}}+\gamma \mathrm{C}_{\mathrm{j}}+\tau \mathrm{S}_{\mathrm{s}} \mathrm{T}_{\mathrm{t}}+\mathrm{u}_{\mathrm{ijt}}
$$

Here, subscript $i$ refers to attributes of each individual and her family, $j$ and $s$ represent the municipality and administrative region where she lives, respectively, and t is the year of observation. In our empirical estimations, we assume that error term $\mathrm{u}_{\mathrm{ijt}}$ is linear and estimate equation (1) with OLS.

If all adolescent girls—-mothers and not—were enrolled in school, we would be able to match all observations to whether their school implemented the reform, and FDS would be measured at the individual level. However, if a teen has dropped out of high school, we do not have information about her individual school's characteristics (including its FDS status), so we only observe adolescents' exposure to full-time schools in their municipality $\left(\right.$ FDS $\left._{\mathrm{jt}}\right)$. Furthermore, the supply of FDS schools at the municipal level is exogenous to teenagers' sexual activity and fertility choices. We will estimate equation (1) with two different, but closely related measures of FDS $S_{\mathrm{jt}}$. First, we will include the proportion of secondary schools in the municipality that offer full-day schooling during a given year, while our second measure is the share of total secondary enrollment at the municipality level that is under full-day schooling. We are interested in , which measures the effect of the reform on the likelihood that adolescents become mothers. 
As Black et al. discuss, the effect of increased education on the likelihood of adolescent motherhood works through two channels: the human capital and the incarceration effects. The objective of the reform is to improve education quality in Chile, on the premise that extending the school day will improve education outcomes. In this case, more time in the classroom—30\% more time-positively impacts human capital—the first channel—-thereby raising permanent lifetime income and expectations about the future. As a result, adolescent motherhood should decrease. Furthermore, fewer hours without adult supervision limit opportunities for risky sexual behavior, which should also be followed by decreases in teen motherhood. This latter channel is what Black et al. refer to as the incarceration effect. A priori, for these two reasons we expect a negative effect of the FDS reform on the likelihood that an adolescent becomes a mother.

In addition to our variable of interest—FDS availability—-the large literature on the determinants of teenage pregnancy provides insight as to appropriate controls. We wish to include individual and family characteristics that are correlated with the likelihood of an adolescent birth $\left(\mathrm{X}_{\mathrm{ijt}}\right)$. Additionally, the social and economic context in which teens live may also affect their fertility decisions, so we include time-varying municipal characteristics $\left(\mathrm{M}_{\mathrm{jt}}\right)$ that are correlated with teen births.

To address the possibility that municipalities with lower levels of wealth and infrastructure may have lower school supply in general, we control for municipal fixed effects to capture these (and other) timeinvariant community characteristics $\left(\mathrm{C}_{\mathrm{j}}\right)$. Finally, we control for economic conditions and other changes occurring at the regional level with a series of region-year dummy variables, $\mathrm{S}_{\mathrm{s}} \mathrm{T}_{\mathrm{t}}$.

\subsection{Potential source of biased $\beta$}

A possible source of bias stems from the mechanism for allocation of public funding for FDS and municipal characteristics. As was discussed above, the Ministry of Education prioritized vulnerable schools located in municipalities with relatively poor populations. If schools located in municipalities with poor socio-economic conditions were given priority to FDS funds, and if these municipalities observed high adolescent motherhood rates, then the estimated coefficient for FDS underestimates the true effect of the reform because it is biased towards zero. 
To test whether this potential bias is present in our data, we regress the variable of interest, FDS, on municipal-level characteristics that reflect the criteria followed by the Ministry of Education as they awarded FDS funds. Specifically, we estimate the following regression:

$$
\mathrm{FDS}_{\mathrm{jt}}=\phi+\rho \mathrm{L}_{\mathrm{jt}}+\Sigma_{t} \varphi_{\mathrm{t}} \mathrm{T}_{\mathrm{t}}+\mathrm{e}_{\mathrm{jt}}
$$

$\mathrm{L}_{\mathrm{jt}}$ includes municipality-level rates of poverty, unemployment, illiteracy and teen motherhood in year $t$. The estimation also includes year dummy-variables to control for the program implementation timetrend, as investments grew through time. We estimate equation (2) linearly and report results in Table 3. As can be observed, FDS implementation was directed towards schools located in under-privileged municipalities. Column (1) presents the cross-sectional correlations between municipal-level characteristics and the rate at which schools in the municipality ascribed to the FDS program. Poorer municipalities had higher shares of FDS schools and although the remaining coefficients are not statistically significant, it is interesting to notice the positive coefficient on teen pregnancy rate.

Column (2) of Table 3 presents results of estimating equation (2) with municipality fixed effects, which reveals the effects of municipal characteristics on the evolution of FDS within the municipality. We find that the evolution of FDS implementation within municipalities is not correlated with any of these observable characteristics-which were important only in the allocation of FDS funds across municipalities (Column 1).

The results of estimating equation (2) suggest that the administrative criteria that directed FDS funds towards schools in poorer municipalities were effective. This implies that if our results are biased, they likely underestimate the true impact of FDS on adolescent motherhood-i.e., the results from our linear estimations are a lower bound of the effect of the FDS reform on motherhood.

\section{Chile’s CASEN Surveys}

Our data on individuals and municipal socio-economic variables comes from Chile's National Socio- 
economic Characterization Survey, CASEN, which has been carried out every two years in Chile since 1990. ${ }^{16}$ The surveys contain individual and family information about education, health, employment and income as well as the household's demographic composition. We limited the sample to teenage girls who are of childbearing and high-school age (15 to 19 years. $)^{17}$ CASENs are also representative at the municipality level, and they provide municipal-level economic variables such as average income, education, unemployment, and poverty rates.

The dependent variable $\mathrm{Y}_{\mathrm{ijt}}$ equals 1 if the adolescent is a mother and 0 otherwise. The objective of the CASEN survey is to measure poverty and access to Chile's social programs, and as such it does not contain women's complete fertility history. We construct the motherhood variable from household composition information, in which all household members report their relationship to the head of the household and to the head of the family nucleus. Since multi-family households are common in Chile, the survey defines a household as being constituted by one or more persons that may or may not be family members and that share a dwelling and food budget. A nuclear family within a household is composed of parents and their unmarried children who do not make up another nuclear family. Although the majority is single-family, $17 \%$ of households in Chile have more than one family living in them.

We define adolescent mothers as women aged 15 to 19 years who either: (i) are the head of their household (HH) or spouse of the $\mathrm{HH}$ and have sons or daughters present in their household, or (ii) are the head of the family nucleus within a larger household and sons/daughters are present in their family unit.

Individual and family characteristics in vector $\mathrm{X}_{\mathrm{ijt}}$ also come from the CASEN surveys, and they include age and years of education completed by the adolescent; demographic composition of the household (number of elderly, number of children aged 6 to 14, and number of adults in the household), sex and years of education of the head of the household; total adult household income, and a dummy for rural location of the household. As a proxy for household wealth we control for household density defined as the number of

\footnotetext{
${ }^{16}$ As of 2000, the CASEN is carried out every 3 years. Our data pools all available years of CASEN data: 1990, 1992, 1994, 1996, 1998, 2000, 2003 and 2006.

${ }^{17}$ The appropriate high school age in Chile is 14-18 years. We exclude 14 year olds because the incidence of motherhood in the age distribution jumps from $0.5 \%$ to $1.9 \%$ between ages 14 and 15 , respectively. We include 19 year-olds to keep grade repeaters in the sample, and because they are considered adolescents. As a robustness check, we estimated regressions with age groups 14-18 and 14 to 19 years, and the results did not change.
} 
persons in the household per number of bedrooms. ${ }^{18}$

We also controlled for whether the adolescent's mother was also a teenage mom. We construct this variable by estimating the difference between age of the teen's mother and her eldest child. The variable equals 1 if the age at first birth of the adolescent's mother is less than 20 years old. Since the construction of this variable requires the presence of the adolescent's mother in the household, we limit the sample to teenage girls who continue to live with their mothers. Furthermore, we do not capture the full effect of this variable because in any given household, the mother's age at first birth may be over-estimated if the oldest child no longer lives in the household. Thus, the measured effect is a lower-bound estimate of the full effect of having a mother who was an adolescent mom.

We don't have systematic information for whether a household benefited from government transfers aimed at reducing high school desertion (scholarships, school supplies, etc.) Nonetheless, these government subsidies were targeted to poor households, so as a proxy for reception of education transfers, we include a dummy variable that is equal to 1 if the household is classified as poor according to the CASEN survey. ${ }^{19}$ Including this variable permits us to isolate the effect of access to FDS schools.

Our estimates also control for time-invariant municipality fixed effects $\left(C_{j}\right)$ and municipality characteristics $\left(\mathrm{M}_{\mathrm{jt}}\right)$ that are correlated with the probability that teenagers are mothers. The CASEN surveys also provide municipal-level variables, such as average years of education, unemployment rate, and income per capita in the municipality. Additionally, to control for changes in economic conditions and long-term trends in adolescent motherhood, we included a set of region-year effects in all estimations.

\subsection{Additional sources of Information}

Ideally, vector $\mathrm{M}_{\mathrm{jt}}$ would include variable(s) that measure the availability or access by teenagers to

\footnotetext{
${ }^{18}$ This variable is also interesting because studies have found it to be correlated with sexually promiscuous behaviors in Chile's public housing (ECLAC, 2005).

${ }^{19}$ Poverty is defined by an absolute poverty line drawn by Chile’s Ministry of Planning based on the CASEN surveys. Government transfers are targeted with another instrument - the Ficha CAS, also administered by the Ministry of Planning-and evaluations have revealed that programs are well-targeted to poor households (Clert and Wodon, 2001).
} 
family planning, i.e., sex education and birth control. ${ }^{20}$ Despite the fact that numerous programs aimed at providing women with access to contraceptive methods exist in Chile, there is no systematic data set of these measures, so that we cannot control for the real use of contraception in our estimations.

As a second-best alternative, we construct municipal-level variables that capture community norms (of social acceptance or stigma) towards teenage births. Using data from the Ministry of Health's National Birth Registry, we construct municipality teenage pregnancy rates, and the average age of first birth.

\subsection{Full-Day Schooling}

As mentioned above, we cannot measure whether the high school that an adolescent attends is offers FDS for all teens in our sample. Thus, we construct variables that measure availability of FDS schools in the municipality in which the adolescent lives.

Data for the variable comes from the Ministry of Education's administrative database, which includes school-level information on their location (municipality), FDS status, year the school changed to FDS, and student enrollment in FDS. We analyze only secondary schools, since these cover the age group of interest. FDS status does not necessarily apply to all students of a given school, for two reasons: (i) many high schools offer more than one track to obtain a high school diploma, and it is possible that in any given year only a subset of programs is full-day; ${ }^{21}$ and (ii) schools may progressively include each year of their degrees to the FDS program, for example, a school may offer full-day schooling to high school Juniors and Seniors but not to Freshmen and Sophomores.

To account for the later effect, we create two FDS variables: the share of high schools in the municipality that offer FDS in at least one of their programs, and the share of student enrollment in the municipality that attends school in a full-day shift. ${ }^{22}$

\footnotetext{
${ }^{20}$ All forms of abortion, including therapeutic ones, are illegal in Chile.

${ }^{21}$ In Chile, secondary schooling is divided in two tracks: a four-year "Science and Humanities" track, which follows a general education curriculum aimed providing access to higher education, and a five-year "Technical-Professional” track, in which students obtain specialization in one of five technical areas: commerce, industry, technology, agriculture, and marine.

${ }^{22}$ As the shift to FDS has occurred across all school sizes, the unconditional correlation among this two variables is positive and large (0.96).
} 


\section{Results}

We find that higher access to FDS schools—-measured as share of number of schools or of FDS enrollment in the municipality of residence-reduces the likelihood that Chilean adolescents become mothers. Table 1 presents our estimated coefficients. Both measures of FDS—share of number of schools (column 1) and share of enrollment (column 2)—yield consistent results (they have almost identical effects), yet the effect of longer school days on teen motherhood is modest: an increase in FDS school coverage of 20 percent reduces teenage motherhood by 3 percent; the impact is the same under both definitions of coverage (share of FDS schools or school enrollment). ${ }^{23}$ Since the effects are almost identical, for ease of exposition, we will only discuss results regarding the effects of number of FDS schools (from Column (1) of Table 5) in the proceeding discussion.

Education is strongly correlated with lower adolescent motherhood: higher educational attainments (for their given age) are less likely to be mothers, and each additional year of education is correlated with a 30 percent lower probability of being an adolescent mother. ${ }^{24}$ Similarly, the likelihood of being a mother increases rapidly with age: after controlling for all observable characteristics, by age 19 a girl is 6 times more likely to be a mother compared to a 16-year old.

Family structure is an important determinant of teenage childbearing. We find that the presence of an elderly person (aged 65 years or more) in the household, most likely a grand parent according to our data, is correlated with a 26 percent lower likelihood of adolescent motherhood. This is probably because teenagers who live with a grandparent are under stricter adult supervision in the after-school hours than those who do not live with a grandparent. We find that the presence of younger siblings (aged 6 to 14) also correlated with lower teen motherhood probabilities, and although the effect is smaller in magnitude than the one for grandparents (14 percent), it suggests that adolescent girls with siblings have greater responsibilities in taking care of younger brothers or sisters, which may reduce time available for activities that may lead to pregnancy

\footnotetext{
${ }^{23}$ The elasticity of the effect is derived as follows: $(\hat{\beta} / \bar{Y}) * \bar{X}$ where $\hat{\beta}$ is the estimated coefficient in Table 5, $\bar{Y}$ is the mean of the dependent variable reported at the bottom of Table 5, and $\bar{X}$ is average FDS coverage in 2006 (Table 2).

${ }^{24}$ Henceforth, marginal effect are estimated as $(\hat{\beta} / \bar{Y})$ reported in Table 5.
} 
and motherhood. In sum, these two results suggest that family structure affects the scope for risky sexual behavior through a chaperone effect (grandparents) and a time constraint (siblings). ${ }^{25}$

Adolescents who live in female-headed households are 31 percent more likely to be teenage moms than those living in homes where the head of the household is a man. This result indicates that the design of public policies should account for the vulnerability faced by teenage girls in single-mother families. ${ }^{26}$

We also find that daughters of teenage mothers are 8 percent more likely to bear children in their adolescent years. This is evidence that family preferences for early childbearing are important in determining teenager's fertility outcomes, and suggests that policies oriented at preventing teen births may have externality or inter-temporal effects into future generations.

Once we control for household demographic composition, the effects of parental income are small: an increase of 1 percent in adult income is correlated with a 2\% lower probability of motherhood. Education of the head of the household does not significantly affect the likelihood of adolescent motherhood, probably because it is strongly correlated with income. Household wealth—as proxied by household density—has important effects on motherhood: each additional household member present per bedroom in the home is correlated with a 37 percent increase in the probability that an adolescent girl is a mother.

Poor adolescents are 26 percent more likely to be mothers relative to non-poor teens, while rural teens are 10 percent less likely to be mothers compared to teenagers in urban areas.

All our estimations include municipality fixed effects. Our results reveal that once we control for these time-invariant differences across municipalities, within-municipality variation in education, income, and unemployment—as well as our proxies for social norms regarding teen pregnancy (municipal teen pregnancy rates and age of first birth)—are not statistically significant determinants of adolescent motherhood.

\subsection{Differences across location and income}

\footnotetext{
${ }^{25}$ Siblings may also produce a chaperone effect.

${ }^{26}$ Our estimations control for whether the head of the household is female, which is almost equivalent to single-mother households: 83 percent of female heads of households are single.
} 
We are interested in analyzing whether results differed across rural and urban location, and across income groups. Thus, we performed our estimations by dividing the sample into urban/rural and into poor and non-poor adolescents following the CASEN classification. Table 6 presents the results for both our definitions of FDS access.

We find that the positive impact that access to full-day schooling is present only in urban areas, and the magnitude of the effect is similar as the average effect of the total population. Both our measures of FDS—number of schools and enrollment—are of similar magnitude.

Furthermore, the effects of full-day schooling are present only among poor adolescents: an increase of 20 percent in FDS access reduces the probability that an adolescent becomes a mother by 5 percent.

\subsection{Robustness checks}

Parents in Chile consider distance in their school choice process, and most studies find that parents choose nearest schools (McEwan, 2003). Yet average distance traveled increases from 2.5 kilometers in primary to 5 kilometers in secondary school (Chumacero et al., 2008). If adolescents travel across municipality lines, then our estimate of $\beta$ may not reflect the true access to FDS schools since our data only contains municipality of residence. Inter-municipal migration to secondary schools is likely to occur more frequently in Chile’s three large metropolitan areas (Santiago, Valparaiso and Concepcion) where distances between towns are small and where inter-municipal transportation is readily available. We test the robustness of our results by excluding these three metropolitan from our estimations to diminish the possibility of contaminating our results. Column (5) of Table 6 contains the results of our regression excluding metro areas, and we find that the coefficient is almost identical to our baseline estimations. Thus, we are assured that our measure of access to full-day schooling is not seriously affected by inter-city migration by high school students.

\section{Concluding remarks}


We analyzed whether an education reform that increased the length of the school day, thereby increasing education and reducing the number of hours that teenagers spend without adult supervision, affected motherhood decisions of Chilean adolescents. The full-day schooling reform exogenously altered time allocation decisions, including time available to engage in risky sexual behavior that can lead to early childbirth. The FDS reform was gradually implemented between 1997 and 2006 (and currently continues its implementation) across Chile’s municipalities, providing a quasi-experimental design and an opportunity to identify whether adolescent motherhood responds to increased time under school supervision.

Our results indicate that greater access to FDS schools—-measured as share of number of schools or of FDS enrollment in the municipality of residence-reduces the likelihood that Chilean adolescents become mothers, although with modest effects: an increase of 20 percent in accessibility to the FDS program reduces teenage motherhood by approximately 3 percent. The effect is present among poor adolescents, whose likelihood of motherhood is reduced by 5 percent with a similar increase in FDS access. Furthermore, the effect is present only in Chile's urban areas, and results are consistent for two definitions of FDS access and to the exclusion metropolitan areas (where our results may imprecisely measure teen's true access to FDS schools due to inter-city commuting to secondary school).

We also find that an additional year of education is correlated with a 30 percent lower probability of adolescent motherhood, revealing that both access to longer school days and educational attainments are important factors that help reduce the incidence of early births.

Beyond hours under their teachers' watch, other forms of supervision of teenager's activities, such as the presence of grandparents and younger siblings in the household, are correlated with lower probabilities of adolescent motherhood. Teenagers whose mother gave birth as an adolescent are more likely to be mothers, even after controlling for adult household income. This suggests that family preferences towards early childbearing may be passed on across generations. Not surprisingly, adolescents living in better economic conditions—higher adult income and higher wealth/lower household density—are less likely to be mothers.

Our findings might suggest caution to critics of the FDS reform in Chile. While the reform has fallen short of delivering its promise of increases in student achievements in test scores, it seems to have spillover 
effects into other aspects of adolescents' lives. Indeed, in the program description, the Ministry of Education recognized that schools are not only centers of learning but also a space that protects socially vulnerable children from risks such as school desertion, drugs, and child labor. The results in this paper show that the FDS program has been somewhat successful in reducing risky sexual behavior among urban, poor adolescents, since higher access to full-day schools has reduced the probability of motherhood among these vulnerable teens. 


\section{References}

Ashcraft, A., Lang, K. 2006. The Consequences Of Teenage Childbearing. NBER Working Paper Series, Working Paper 12485.

Becker, G., Lewis, H.G. 1973. On the Interaction Between the Quantity and Quality of Children. Journal of Political Economy, 81 (2), S279-S288.

Black, S.E., Devereux, P.J., Salvanes, K.G. 2008. Staying in the classroom and out of the maternity ward? The effect of compulsory schooling laws on teenage births. The Economic Journal, 118, 1025-1054.

Cabrera, S. 2008. "Restricciones de Tiempo: Trabajo v. Cuidado de los Hijos. ¿Es la Jornada Escolar Completa una solución?” University of Chile Masters Thesis.

Chay, K., McEwan, P. J., \& Urquiola, M. 2005.The central role of noise in evaluating interventions that use test scores to rank schools. American Economic Review, 95(4), 12371258.

Chumacero, R.A., Gomez, D., Paredes, R.D. 2008. I Would Walk 500 Miles (if it paid). University of Chile, Mimeo.

Clert, C., Wodon, Q. 2001. The Targeting of Government Programs in Chile: A Quantitative and Qualitative Assessment, in Chile: Poverty and Income Distribution in a High Growth Economy, World Bank Poverty Assessment - Vol. 2, World Bank Report No. 22037, 99-126.

ECLAC (Economic Commission for Latin America and the Caribbean). 2005. Políticas sociales de vivienda, pobreza y ciudadanía en Chile: Un estudio de caso desde la etnografía. Mimeo, Proyecto Regional de Población CELADE-UNFPA.

Fletcher, J.M., Wolfe, B.L. 2008. Education And Labor Market Consequences Of Teenage Childbearing: Evidence Using The Timing Of Pregnancy Outcomes And Community Fixed Effects. NBER Working Paper Series, Working Paper 13847.

Garcia, A. 2006. Evaluacion del Impacto de la Jornada Escolar Completa. University of Chile Masters Thesis.

Gallego, F. (2002). Competencia y resultados educativos: teoría y evidencia para Chile.Cuadernos de Economía, 39(118).

Grossman, M. 1972. On the Concept of Health Capital and the Demand for Health. Journal of Political Economy, 80 (2), 223-255.

Hoffman, S. D. 1998. Teenage Childbearing Is Not So Bad After All...Or Is It? A Review of the New Literature. Family Planning Perspectives, Vol. 30, No. 5. 236-239,243.

Hsieh, C., Urquiola, M. 2006. The effects of generalized school choice on achievement and stratification: Evidence from Chile's school voucher program. Journal of Public Economics, 90, 1477-1503.

Jacob, B.A., Lefgren, L. 2003. Are Idle Hands the Devil's Workshop? Incapacitation, Concentration, and Juvenile Crime. The American Economic Review, 93(5), 1560-1577.

McCrary, J., Royer, H. 2006. The Effect Of Female Education On Fertility And Infant Health: Evidence From School Entry Policies Using Exact Date Of Birth. NBER Working Paper Series, Working Paper 12329. 
McEwan, P. 2003. Peer effects on student achievement: evidence from Chile, Economics of Education Review 22, 131-141.

Mizala, A., \& Romaguera, P. 2000. School performance and choice. Journal of Human Resources, 35(2), 392-417.

Valenzuela, J.P. 2005. "Partial Evaluation of a Big Reform in the Chilean Education System: From a Half Day to a Full Day Schooling.” University of Michigan Doctoral Dissertation.

Wolfe, B., Haveman, R., Pence, K., Schwabish, J.A. 2007. Do youth nonmarital childbearing choices reflect income and relationship expectations? Journal of Population Economics, 20, 73-100.

Wolfe, B., Wilson, K., Haveman, R. 2001. The role of economic incentives in teenage nonmarital childbearing choices. Journal of Public Economics, 81, 473-511. 
Figure 1

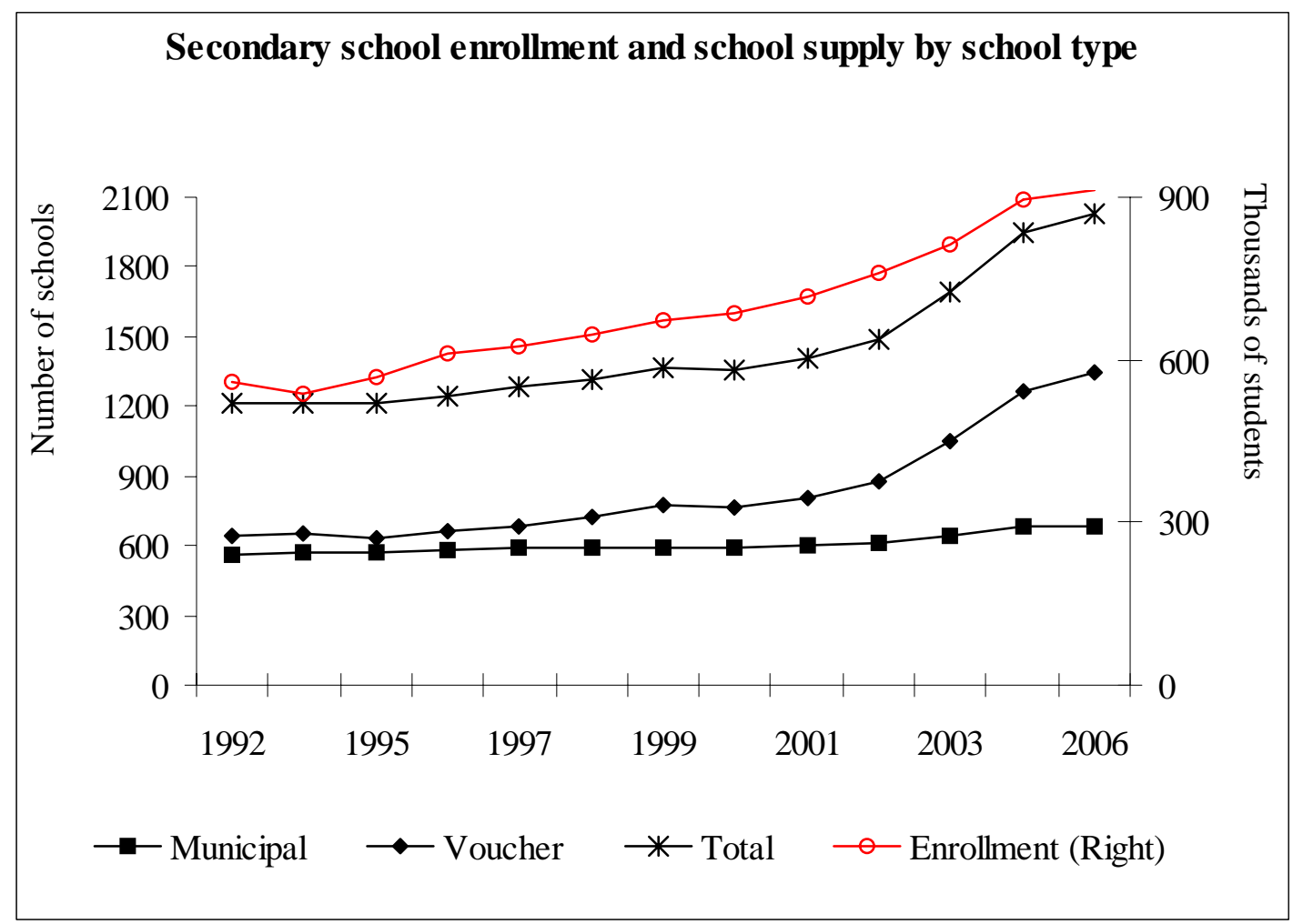

Authors' estimates based on administrative data from the Ministry of Education. 
Figure 2

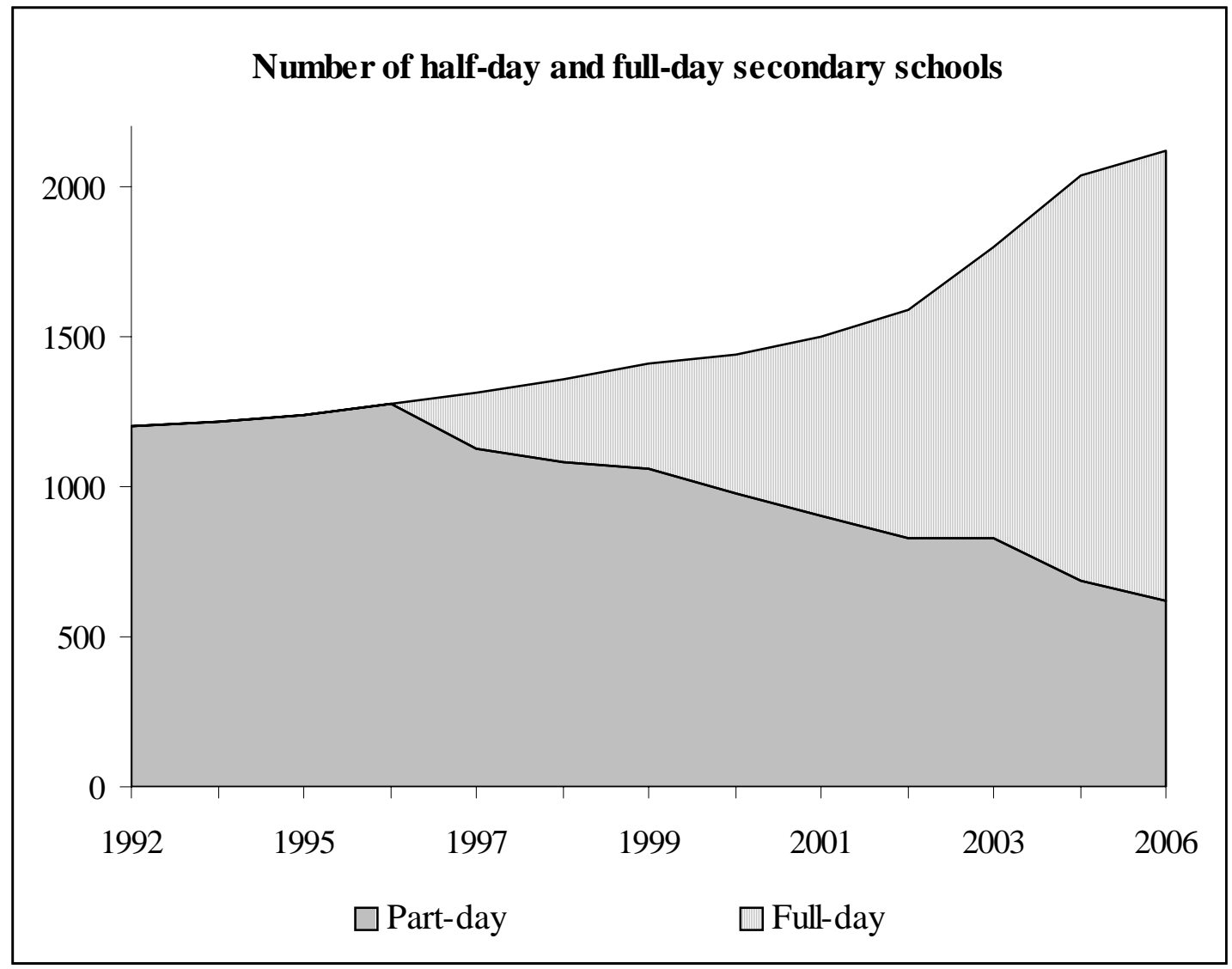

Authors' estimates based on administrative data from the Ministry of Education. 
Figure 3

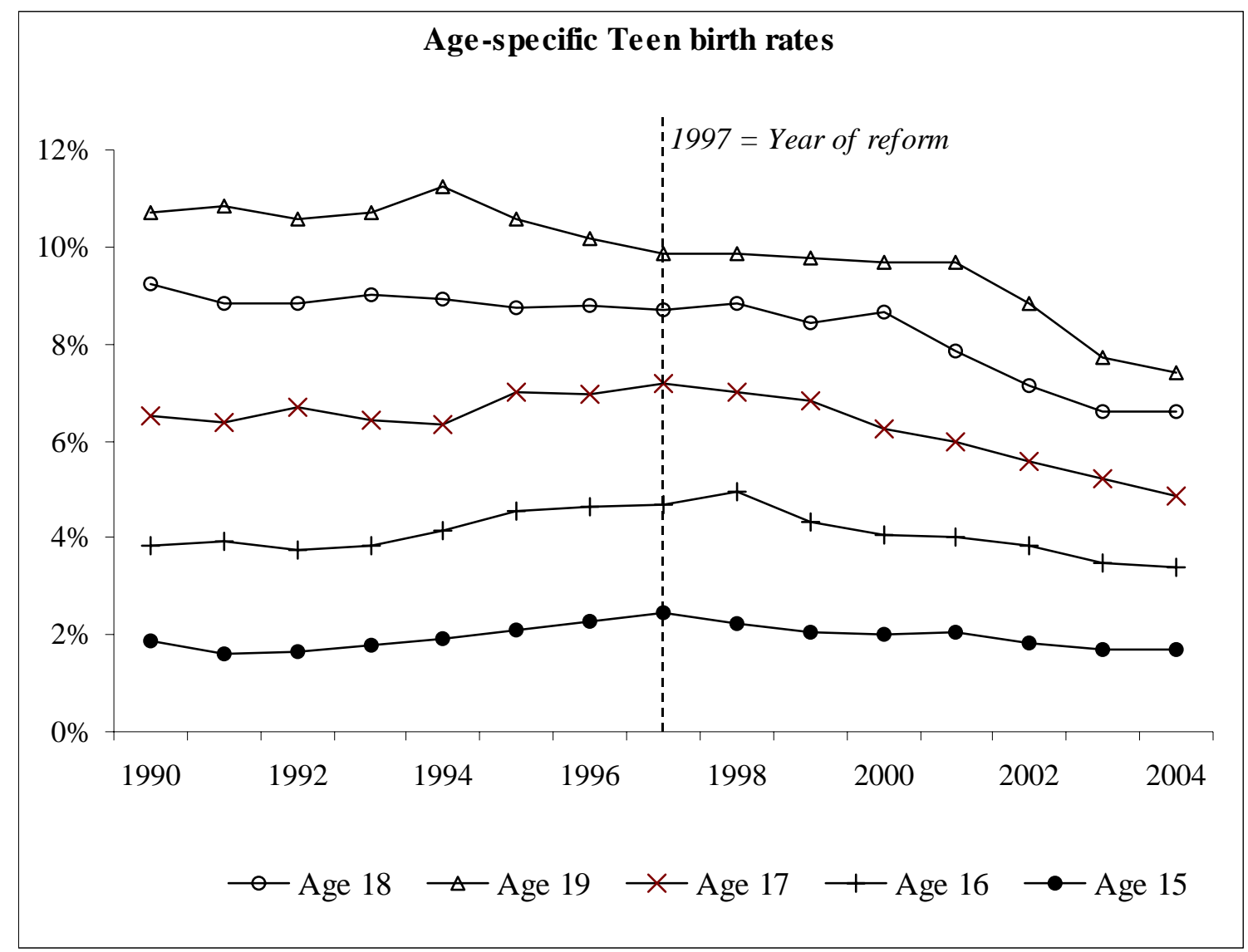

Note: Authors' estimates based on: Ministry of Health - National Birth Registry; National Institute of Statistics - Population Projections; Ministry of Education - School Directory Database. 
Table 1

Chile: Age-specific teenage birth rates, 1990 - 2004

\begin{tabular}{c|ccccc|c}
\hline \hline & \multicolumn{5}{|c|}{ Age } & \\
Year & 15 & 16 & 17 & 18 & 19 & Cumulative \\
\hline \hline 1990 & 1.9 & 3.9 & 6.5 & 9.2 & 10.7 & 32.2 \\
1991 & 1.6 & 3.9 & 6.4 & 8.8 & 10.9 & 31.6 \\
1992 & 1.6 & 3.8 & 6.7 & 8.8 & 10.6 & 31.5 \\
1993 & 1.8 & 3.9 & 6.4 & 9.0 & 10.7 & 31.8 \\
1994 & 1.9 & 4.1 & 6.4 & 8.9 & 11.2 & 32.6 \\
1995 & 2.1 & 4.5 & 7.0 & 8.7 & 10.6 & 32.9 \\
1996 & 2.3 & 4.7 & 6.9 & 8.8 & 10.2 & 32.8 \\
1997 & 2.5 & 4.7 & 7.2 & 8.7 & 9.8 & 32.9 \\
1998 & 2.2 & 4.9 & 7.0 & 8.8 & 9.8 & 32.8 \\
1999 & 2.0 & 4.3 & 6.8 & 8.4 & 9.8 & 31.4 \\
2000 & 2.0 & 4.1 & 6.3 & 8.6 & 9.7 & 30.7 \\
2001 & 2.0 & 4.0 & 6.0 & 7.8 & 9.7 & 29.6 \\
2002 & 1.8 & 3.8 & 5.6 & 7.2 & 8.8 & 27.3 \\
2003 & 1.7 & 3.5 & 5.2 & 6.6 & 7.7 & 24.7 \\
2004 & 1.7 & 3.4 & 4.9 & 6.6 & 7.4 & 24.0 \\
\hline \hline
\end{tabular}

Authors' estimates based on Ministry of Health's National Birth Registry and Population Census Projections. Table measures proportion of age-specific population that gave birth in a given year. 
Table 2

Proportion of FDS schools (\%) by Administrative Region, 1997 - 2006

\begin{tabular}{|c|c|c|c|c|c|c|c|c|c|c|c|}
\hline $\begin{array}{l}\text { Chilean } \\
\text { Administrative } \\
\text { Region }\end{array}$ & 1997 & 1998 & 1999 & 2000 & 2001 & 2002 & 2003 & 2004 & 2005 & 2006 & $\begin{array}{c}\text { Share of } \\
\text { National } \\
\text { Enrollment }^{\text {a }} \\
(\%)\end{array}$ \\
\hline I & 9 & 15 & 22 & 29 & 38 & 40 & 46 & 50 & 57 & 61 & 3.1 \\
\hline II & 18 & 27 & 32 & 42 & 46 & 58 & 66 & 67 & 76 & 79 & 3.3 \\
\hline III & 36 & 50 & 48 & 52 & 52 & 56 & 60 & 65 & 76 & 76 & 2.0 \\
\hline IV & 15 & 25 & 28 & 36 & 45 & 51 & 56 & 62 & 77 & 81 & 4.3 \\
\hline $\mathbf{V}$ & 9 & 13 & 17 & 24 & 33 & 46 & 51 & 57 & 62 & 67 & 9.9 \\
\hline VI & 11 & 12 & 16 & 26 & 34 & 41 & 47 & 51 & 62 & 68 & 5.3 \\
\hline VII & 12 & 19 & 27 & 27 & 38 & 51 & 55 & 58 & 61 & 67 & 6.5 \\
\hline VIII & 12 & 15 & 23 & 27 & 37 & 47 & 56 & 60 & 66 & 69 & 13.0 \\
\hline IX & 30 & 37 & 45 & 44 & 59 & 61 & 63 & 74 & 79 & 82 & 6.6 \\
\hline $\mathbf{X}$ & 30 & 35 & 39 & 46 & 54 & 65 & 68 & 74 & 79 & 85 & 7.4 \\
\hline XI & 42 & 50 & 58 & 67 & 69 & 64 & 88 & 89 & 95 & 95 & 0.7 \\
\hline XII & 36 & 44 & 56 & 59 & 65 & 62 & 81 & 81 & 86 & 91 & 0.9 \\
\hline $\mathbf{R M}$ & 9 & 15 & 20 & 29 & 36 & 42 & 50 & 56 & 63 & 69 & 37.1 \\
\hline TOTAL & 9 & 15 & 20 & 29 & 36 & 42 & 50 & 56 & 63 & 69 & 100.0 \\
\hline
\end{tabular}

\footnotetext{
${ }^{\text {a }}$ Share of enrollment is for 2006. The distribution did not change during the period.
}

Authors' estimates using Ministry of Education FDS database. The table includes the proportion of secondary schools in each of Chile's administrative Regions that had implemented the FDS program in at least one of its grade levels. RM = Santiago metropolitan region. 
Table 3

Determinants of Implementation of Full-Day Schooling

Dependent Variable:

Share of Full-Day Schools in Municipality

(1)

(2)

\begin{tabular}{|c|c|c|}
\hline Variables & Cross-section & $\begin{array}{l}\text { Municipality } \\
\text { Fixed effects }\end{array}$ \\
\hline Poverty rate & $\begin{array}{l}0.00178 * * \\
(0.001)\end{array}$ & $\begin{array}{l}0.000583 \\
(0.001)\end{array}$ \\
\hline Unemployment rate & $\begin{array}{l}1.78 \mathrm{E}-05 \\
(0.002)\end{array}$ & $\begin{array}{l}-0.000392 \\
(0.002)\end{array}$ \\
\hline Illiteracy rate & $\begin{array}{l}-0.00182 \\
(0.002)\end{array}$ & $\begin{array}{l}-0.00241 \\
(0.004)\end{array}$ \\
\hline Teen motherhood rate & $\begin{array}{l}0.178 \\
(0.345)\end{array}$ & $\begin{array}{l}0.298 \\
(0.490)\end{array}$ \\
\hline Year 1992 & $\begin{array}{l}0.00572 \\
(0.007)\end{array}$ & $\begin{array}{l}-0.0111 \\
(0.019)\end{array}$ \\
\hline Year 1994 & $\begin{array}{l}0.0102 \\
(0.008)\end{array}$ & $\begin{array}{l}-0.00984 \\
(0.021)\end{array}$ \\
\hline Year 1996 & $\begin{array}{l}0.0216^{* *} \\
(0.011)\end{array}$ & $\begin{array}{l}-0.0348 \\
(0.025)\end{array}$ \\
\hline Year 1998 & $\begin{array}{l}0.187 * * * \\
(0.024)\end{array}$ & $\begin{array}{l}0.144^{* * *} \\
(0.028)\end{array}$ \\
\hline Year 2000 & $\begin{array}{l}0.302 * * * \\
(0.025)\end{array}$ & $\begin{array}{l}0.250 * * * \\
(0.029)\end{array}$ \\
\hline Year 2003 & $\begin{array}{l}0.597 * * * \\
(0.026)\end{array}$ & $\begin{array}{l}0.538 * * * \\
(0.032)\end{array}$ \\
\hline Year 2006 & $\begin{array}{l}0.806^{* * *} \\
(0.025)\end{array}$ & $\begin{array}{l}0.743^{* * *} \\
(0.036)\end{array}$ \\
\hline Constant & $\begin{array}{l}-0.0712^{* *} \\
(0.030)\end{array}$ & $\begin{array}{l}0.00481 \\
(0.060)\end{array}$ \\
\hline Observations & 1657 & 1653 \\
\hline R-squared & 0.554 & 0.785 \\
\hline
\end{tabular}


Table 4

Sample Summary Statistics

\begin{tabular}{|c|c|c|c|c|c|c|}
\hline \multirow{2}{*}{ Variables } & \multicolumn{2}{|c|}{ ALL } & \multicolumn{2}{|c|}{ NON-POOR ${ }^{\text {a }}$} & \multicolumn{2}{|c|}{ POOR $^{a}$} \\
\hline & Mean & St.Dev. & Mean & St.Dev. & Mean & St.Dev. \\
\hline \multicolumn{7}{|l|}{ Dependent Variable: Adolescent is a mother } \\
\hline Average & 0.067 & 0.251 & 0.055 & 0.229 & 0.094 & 0.291 \\
\hline \multicolumn{7}{|l|}{ Age-spefic rates: } \\
\hline At age 15 & 0.014 & 0.119 & 0.010 & 0.099 & 0.024 & 0.152 \\
\hline At age 16 & 0.031 & 0.172 & 0.023 & 0.150 & 0.046 & 0.210 \\
\hline At age 17 & 0.063 & 0.242 & 0.051 & 0.219 & 0.089 & 0.284 \\
\hline At age 18 & 0.101 & 0.301 & 0.080 & 0.272 & 0.149 & 0.356 \\
\hline At age 19 & 0.156 & 0.363 & 0.131 & 0.337 & 0.224 & 0.417 \\
\hline \multicolumn{7}{|l|}{ Individual Variables } \\
\hline Years of education & 10.1 & 2.1 & 10.3 & 2.0 & 9.6 & 2.2 \\
\hline Age & 16.9 & 1.4 & 16.9 & 1.4 & 16.8 & 1.4 \\
\hline \multicolumn{7}{|l|}{ Household Variables } \\
\hline Num. Siblings aged 6-14 & 0.8 & 0.9 & 0.7 & 0.8 & 1.2 & 1.1 \\
\hline Yrs. of Educ.-Head of household & 8.0 & 4.3 & 8.7 & 4.4 & 6.5 & 3.6 \\
\hline Adult hhold income p/capita (log) ${ }^{\mathrm{b}}$ & 91,876 & 188,601 & 123,534 & 219,864 & 21,711 & 11,145 \\
\hline Household density ${ }^{c}$ & 2.1 & 1.1 & 1.9 & 0.9 & 2.6 & 1.3 \\
\hline Female-headed hhold. & 0.20 & 0.40 & 0.18 & 0.38 & 0.24 & 0.43 \\
\hline Mother gave birth as teen ${ }^{d}$ & 0.24 & 0.43 & 0.22 & 0.42 & 0.29 & 0.45 \\
\hline Num. of elderly in Household (65yrs+) & 0.13 & 0.39 & 0.15 & 0.42 & 0.10 & 0.34 \\
\hline Household is poor ${ }^{a}$ & 0.31 & 0.46 & 0.00 & 0.00 & 1.00 & 0.00 \\
\hline Rural location & 0.31 & 0.46 & 0.32 & 0.47 & 0.30 & 0.46 \\
\hline \multicolumn{7}{|l|}{ Municipality-level Variables } \\
\hline FDS schools in municipality (\%) & 0.35 & 0.40 & 0.37 & 0.40 & 0.30 & 0.39 \\
\hline FDS enrollment in municipality (\%) & 0.33 & 0.40 & 0.35 & 0.40 & 0.28 & 0.39 \\
\hline Municipal average yrs. Education & 8.8 & 1.5 & 9.0 & 1.5 & 8.4 & 1.3 \\
\hline Municipal unemployment rate (\%) & 8.3 & 3.8 & 8.1 & 3.7 & 8.8 & 4.0 \\
\hline Municipal average income ${ }^{\mathrm{b}}$ & \multicolumn{2}{|c|}{$440,883330,411$} & \multicolumn{2}{|c|}{$476,061374,600$} & \multicolumn{2}{|c|}{$362,918176,940$} \\
\hline Municipal teen pregnancy rate & 0.06 & 0.02 & 0.06 & 0.02 & 0.07 & 0.02 \\
\hline Municipal ave. mother's age at first birth & 22.4 & 1.2 & 22.5 & 1.3 & 22.2 & 1.1 \\
\hline Number of Observations & 50,837 & & 34,824 & & 16,013 & \\
\hline
\end{tabular}

From CASEN data (1990, 1992, 1994, 1996, 1998, 2000, 2003, and 2006), Ministry of Education - Enrollment Database 1990-

${ }^{\text {a }}$ Poverty classification according to CASEN survey/Ministry of Planning of Chile.

${ }^{\mathrm{b}}$ Measured in 2006 pesos. Exchange rate $=530$ pesos/US\$1.

${ }^{\mathrm{c}}$ Number of household members per number of bedrooms.

${ }^{\mathrm{d}}$ Adolescent's mother had her first child as a teen. 
Table 5

Effect of Full-Day Schooling on Adolescent Motherhood

Municipality Fixed Effects Regressions

(1)

(2)

FDS schools in municipality (proportion)

FDS enrollment in municipality (proportion)

Individual and Household Variables

Years of education

Age 16

Age 17

Age 18

Age 19

Num. Siblings aged 6-14

Educ. Head of household

Adult hhold income p/capita (log)

Household density

Female-headed hhold.

Mother gave birth as teen

Num. Elderly in Household (65yrs+)

Household is poor

Rural location

Municipality Variables

Municipal average yrs. Education

Municipal unemployment rate (\%)

Municipal average income (log)
$-0.0124$

$(0.0065) *$

$-0.0108$

$(0.0061)^{*}$

$-0.0201$

$-0.0201$

$(0.0008)^{* * *}$

0.0322

$(0.0008)^{* * *}$

0.0322

$(0.0022)^{* * *}$

0.0782

$(0.0030)^{* * *}$

$(0.0030)^{* * *}$

0.1266

$(0.0037)^{* * *}$

0.1932

$(0.0048)^{* * *}$

$-0.0095$

$(0.0013)^{* * *}$

$-0.0004$

$(0.0003)$

$-0.0015$

$(0.0008)^{* *}$

0.0252

$(0.0014)^{* * *}$

0.021

$(0.0030)^{* * *}$

0.0056

$(0.0027)^{* *}$

$-0.0174$

$(0.0023)^{* * *}$

0.0174

$(0.0031)^{* * *}$

$-0.0067$

$(0.0031)^{* *}$

0.1266

$(0.0037)^{* * *}$

0.1932

$(0.0048)^{* * *}$

$-0.0095$

$(0.0013)^{* * *}$

$-0.0004$

(0.0003)

$-0.0015$

$(0.0008)^{* *}$

0.0252

$(0.0014)^{* * *}$

0.021

$(0.0030)^{* * *}$

0.0056

$(0.0027)^{* *}$

$-0.0174$

$(0.0023)^{* * *}$

0.0174

$(0.0031)^{* * *}$

$-0.0066$

$(0.0031)^{* *}$
0.0016

0.0017

$(0.0038)$

(0.0038)

$-0.0005$

$-0.0005$

(0.0005)

0.0104

(0.0085)
(0.0005)

0.0105

(0.0085) 
Constant

Observations

50,837

50,837

R-squared

0.1

0.1

Mean of Dependent Variable

0.067

0.067

Data: Chilean CASEN Surveys (1990-2006), Ministry of Education Enrollment Database (1990-2006), and Ministry of Health National Birth Registry (1990-2004). Regressions include adolescent girls aged 15-19 years.

Robust standard errors in parentheses. Errors are clustered at the municipality level. * significant at $10 \%$; ** significant at $5 \%$; *** significant at $1 \%$. Not shown: dummy variables for region-year. 
Table 6

Effect of Full-Day Schooling on Adolescent Motherhood: Sample Sensitivity Analyses Municipality Fixed-Effects Regressions

(1)

Urban
(2)

(3)

(4)

Rural

Non-Poor

Poor

(5)

No Metro

Areas

Full-day Measures:

\section{FDS schools in municipality \\ (proportion)}

Observations

R-squared

\section{FDS enrollment in municipality (proportion)}

Observations

R-squared

Mean of Dependent Variable
0.065
$-0.0189$

$(0.0088)^{* *}$

34,824

0.11

$-0.0035$

$-0.0056$

$-0.028$

$-0.0121$

(0.0101)

(0.0075)

$(0.0131)^{* *}$

$(0.0071)^{*}$

$16,013 \quad 35,031$

15,806

41,498

0.11

0.09

0.13

0.10

$0.13 \quad 0.10$

Areas

